\title{
Pembaruan Hukum Nasional: Pruralisme, Unifikasi Hukum, dan Hubungan Kewenangan antara Pemerintah Pusat dengan Pemerintah Daerah
}

\author{
F.C. Susila Adiyanta \\ Fakultas Hukum, Universitas Diponegoro \\ susilafhundip@gmail.com
}

\begin{abstract}
This study aims to identify and reconstruct various issues of national law as the basic framework for national legal reform. The results of the study obtained conclusions: a) the establishment of a modern legal system in Indonesia that is multi-cultural is a challenge for the unification and renewal of national law; b) renewal of national law is a political process whose success depends on the balance of power between the actors involved and the available mementum, so that legal reform requires space and place for the dialectical process involving all components and elements that represent all citizens of a pluralistic society. Recommendations for consideration of renewal of national law are: b) Social, cultural, cultural and Indonesian diversity are the main social capital and capital capital for national legal reforms that adopt values that become the life and soul views of the nation; b) Establishment of national law must be based on values of diversity and not a form of uniformity based on a political process that considers various aspects of deliberation and consensus for the unity and unity of the Indonesian nation.
\end{abstract}

Keywords: Renewal of National Law, Pluralism, Unification, Government Authority

\begin{abstract}
Abstrak
Penelitian ini bertujuan untuk mengidentifikasi dan merekonstruksi ulang berbagai permasalahan hukum nasional sebagaimkerangka dasar pembaruan hukum nasional. Hasil kajian diperoleh simpulan: a) pembentukan satu sistem hukum modern di Indonesia yang multi kultural adalah suatu tantangan bagi unifikasi dan pembaruan hukum nasional; b) pembaruan hukum nasional adalah proses politik yang keberhasilannya tergantung pada perimbangan kekuatan antar aktor yang terlibat di dalamnya serta mementum yang tersedia, sehingga pembaruan hukum memerlukan ruang dan tempat bagi proses dialektika yang melibatkan seluruh komponen dan unsur yang merepresentasikan seluruh warga masyarakat yang majemuk. Rekomendasi untuk pertimbangan bagi pembaruan hukum nasional adalah: b) Keberagaman sosial, budaya, adat-istiadat, dan tradisi masyarakat Indonesia merupakan modal sosial dan modal kapital utama untuk reformasi hukum nasional yang mengadopsi nilai-nilai yang menjadi pandangan hidup dan jiwa bangsa; b) Pembentukan hukum nasional harus dilandasi nilai-nilai keberagaman dan bukan merupakan bentuk penyeragaman berdasarkan proses politik yang mempertimbangkan berbagai aspek musyawarah da mufakat untuk persatuan dan kesatuan bangsa Indonesia.
\end{abstract}

Kata Kunci:Pembaruan Hukum Nasional, Pluralisme, Unifikasi, Pemerintah 


\section{A. Pendahuluan}

Indonesia yang terdiri dari ribuan pulau dan suku bangsa merupakan realitas yang merupakan modal kapital, sosial, dan budaya bangsa. Pruralisme budaya hukum merupakan modal kekayaan dalam melaksanakan unifikasi dan pembangunan hukum nasional, sepanjang proses perumusan hukum nasional melalui proses deliberasi di parlemen mampu menampung dan mengakomodir kepentingan seluruh komponen masyarakat Indonesia yang majemuk. Demikian pula keberagaman sosial, budaya, sumber daya alam dan manusia pada dasarnya adalah aset bagi negara, sehingga dengan pelaksanaan otonomi dan desentrasilsasi kewenangan daerah dapat dioptimalkan untuk mewujudkan kesejahteraan seluruh bangsa.

Dengan latar belakang keberagaman sosial, budaya, ekonomi, dan kepercayaan, serta adat-istiadat yang menjadi ciri khas bangsa Indonesia, identifikasi permasalahan hukum nasional dengan tema ini antara lain meliputi hal-hal : pertama, sejak krisis ekonomi tahun 1997 dan bergulirnya reformasi, pemerintah dan masyarakat indonesia secara intensif dipaksa untuk menerima kenyataan bahwa banyak peristiwa-peristiwa hukum yang bersentuhan dengan masalah legitimasi dan eksistensi bangsa terutama berkaitan dengan latar belakang masyarakat Indonesia yang majemuk (prural).

Kedua, dengan wacana otonomi daerah dan sistem desentralisasi kewenangan, justru banyak peristiwa yang menyangkut pergolakan dan konflik muncul di beberapa wilayah Negara Kesatuan Republik Indonesia (NKRI), diantaranya keinginan beberapa wilayah yang berniat memisahkan diri dari NKRI, merupakan suatu alasan yang cukup untuk kembali menggali konsep dasar negara, rumusan ketatanegaraan dan pembangunan hukum nasional yang berbasis pada nilai-nilai keberagaman masyarakat.

Alasan ketiga, dilakukannya beberapa kali perubahan/ amandemen UUD 1945 yang menjadi titik tolak utama dalam mencari formasi yang paling tepat terhadap fungsi dan kedudukan lembaga-lembaga negara. Adanya perubahan yang signifikan pada konstitusi negara yang demikian ini, semestinya diikuti dengan perombakan kehidupan bernegara dan kehidupan hukum secara fundamental. Namun suatu kenyataan yang dihadapi masyarakat adalah kondisi penegakan hukum yang hanya berjalan di tempat. Hukum justru terlihat bergantung pada kekuasaan. Berkaitan dengan hal ini, maka perlu dipikirkan kembali secara mendalam arti dan makna dari " negara (berdasarkan pada) hukum (rechtstaat)" seperti diamanatkan konstitusi. 
Selain itu sebagai alasan keempat adalah perlu pula suatu kajian dan pemahaman yang lebih mendalam tentang pembangunan dan pengembangan hukum negara Indonesia yang cocok dengan nilai-nilai masyarakat Indonesia, sekaligus menyaring transfer konsep-konsep asing yang memasuki ranah hukum Indonesia yang tidak sesuai dengan kepribadian bangsa. Dengan demikian, menjadi tugas seluruh komponen bangsa Indonesia untuk menggali perkembangan pengertian rule of law maupun negara hukum (rechtstaat) sebagaimana dimaksudkan oleh para Bapak pendiri bangsa (the founding father) seperti dirumuskan di dalam penjelasan UUD 1945.

Berbagai perspektif dan diskursus tentang negara hukum di Indonesia dalam rangka mendukung pembaruan hukum nasional, salah satunya adalah beberapa tulisan, diskusi, dan pemikiran yang mengemuka pada semiloka, seminar, serta berbagai diskusi yang diselenggarakan oleh lembaga-lembaga pemerintah, lembaga-lembaga swadaya masyarakat, maupun institusi akademik. Dari berbagai aktifitas dan kegiatan tersebut ini dapat diidentifikasi rumusan permasalahan- permasalahan sebagai berikut: Bagaimana realitas kondisi pruralitas masyarakat Indonesia, unifikasi hukum, dan pergeseran sistem penyelenggaraan otonomi daerah dalam memberikan kontribusi bagi pembaruan hukum nasional.

\section{B. Pembahasan}

\section{Realitas Kemajemukan Hukum dalam Masyarakat Indonesia}

Indonesia sebagai suatu bangsa, masyarakatnya majemuk, terdiri dari berbagai suku bangsa dan kebudayaan, sehingga secara logis juga memiliki budaya hukum yang sangat beragam. Sejalan dengan perkembangan waktu dan keadaan, budaya hukum milik masyarakatpun juga bisa berubah. Dalam tatanan kehidupan negara yang sedang berkembang, kebudayaan-kebudayaan, tradisi, dan adat istiadat masyarakat seringkali posisinya semakin terkikis, terpinggirkan, dan semakin tidak dominan.

Fakta formal yang terjadi dalam pembangunan hukum di Indonesia adalah semakin dominan dan menguatnya hukum negara (law state) tanpa dibarengi dengan adanya ruang bagi keberadaan sistem-sistem hukum lain (the other law), sehingga menjadi terpinggirkan dan tercecer. Intervensi kebijakan negara terhadap kemajemukan budaya hukum ini, dalam jangka panjang akan mempunyai dampak bagi melemahnya kemajemukan hukum (weak legal pruralism), yang sebenarnya mampu memperkaya 
khasanah hukum nasional yang mampu memelihara nilai-nilai kearifan lokal ${ }^{1}$. Secara historis dapat dilihat gambaran masyarakat majemuk pada era kolonial yang yang cenderung lebih bergantung kepada situasi politik dan ekonomi penguasa pada masa itu. Dengan masyarakat yang multietnik, kebijakan penguasa yang berpihak pada kelompok tertentu, maka fungsi ekonomi dan politik juga mempunyai kecenderungan didominasi oleh kelompok etnik dan golongan tertentu ${ }^{2}$.

Hal yang demikian ini menjadi kendala yang sangat pelik dalam pembangunan sistem hukum Indonesia. Beberapa permasalahan yang timbul sebagai akibat dari kemajemukan hukum di Indonesia, sebagian besar berkaitan dengan kebijakan negara dan yang muncul dan berkembang dalam masyarakat yang prular, yaitu ${ }^{3}$ :

1) masalah hubungan antara state law dengan the other laws. Gejala ini sering tercermin dalam berbagai peristiwa dan telaah pada kondisi masyarakat adat di sekitar hutan. Seperti halnya peristiwa kooptasi negara dalam bentuk aturan negara yang mengatur dan menata daerah hutan. Begitu pula dengan masalah kepemilikan dan peguasaan hak-hak atas tanah yang seringkali diintervensi oleh kepentingan ekonomi dan eksploitasi dengan dalih untuk kepentingan pembangunan nasional. Seringkali benturan terjadi sebagai akibat adanya pihak-pihak yang menggunakan state law untuk kemudian dibenturkan dengan masyarakat adat atau lokal yang menggunaka sistem hkum adat.

2) Hubungan mayoritas denga minoritas. Di bidang ekonomi misalnya, bila mayoritas penduduk (yang memiliki kemampuan ekonomi lemah) dilindungi oleh peraturan pemerintah tertentu (seperti yang terjadi pada masa orde baru), atau sebaliknya golongan elit yang mendapat perlakuan istimewa, akan memicu diskriminasi dan kecemburuan sosial ekonomi yang berpotensi mengancam disintegrasi bangsa.

3) Kondisi kemajemukan yang menyangkut hubungan pribumi dan non pribumi dengan membuat aturan serta perlakukan yang berbeda juga merupakan pemicu permasalahan sosial, ekonomi dan rasial.

\footnotetext{
${ }^{1}$ Djaka Suhenedra, Realitas Kemajemukan Hukum Dalam Masyarakat, Paper untuk Semiloka bertema “ Perkembangan Konsep dan Konteks Negara Hukum di Indonesia” yang diselenggarakan atas kerjasam PSHK, HuMa, dan Fakultas Hukum Universitas Parahiyangan, Bandung, 24 September 2004. Dapat dibaca pula dalam Jurnal Hukum "Jentera" Edisi 3 Tahun II, November 2004, hlm. 11

${ }^{2}$ Ibid., hlm. 12

${ }^{3}$ Op..cit. hlm. 8
} 
4) Hubungan antar suku bangsa diberbagai daerah yang semakin rentan, akibat kebijakan pemerintah pusat yang lebih mengedepankan kepentingan negara yang mengakibatkan kebudayaan dan posisi masyarakat lokal semakin terpinggirkan, mengakibatkan friksi antar kelompok masyarakat yang semakin menguat.

Dengan latar belakang berbagai permasalahan kemajemukan budaya hukum di Indonesia, maka pembaruan hukum di Indonesia semakin dituntut untuk lebih memperhatikan berbagai aspek, diantaranya mencakup: keagamaan, etnik, masalah kaum migran, atau bentuk-bentuk aturan yang diterapkan pada pranata-pranata sosial tertentu.

Demikian pula perlu adanya dorongan untuk melakukan studi antropologi hukum dengan pendekatan legal pruralism dalam pembaruan hukum nasional. Pendekatan kemajemukan hukum bagi pembaruan hukum di Indonesia merupakan hal yang diperlukan, karena adanya kenyataan bahwa kondisi masyarakat dan kebudayaannya yang majemuk (prural). Masyarakat Indonesia yang mempunyai latar belakang agama, budaya, nilai-nilai adat, tradisi, dan kondisi lingkungan yang beragam, merupakan faktor utama bagi pertimbangan dalam pembentukan dan pembangunan hukum nasional yang mampu mengakomodasikan beragam kepentingan dan latar belakang tersebut.

\section{Kebijakan Unifikasi Hukum}

Indonesia sebagai bangsa yang telah merdeka lepas dari penjajah membutuhkan pengembangan hukum nasional yang diharapkan menjadi perekat maupun ikatan solidaritas kehidupan berbangsa dan bernegara. Dengan kenyataan adanya keberagaman suku bangsa, ras, dan agama, pengembangan sistem hukum nasional akan diarahkan untuk mempersatukan dan menjaga keutuhan negara dan bangsa Indonesia. Dengan melalui proklamasi kemerdekaan, bangsa Indonesia yang bersepakat membentuk negara Indonesia seharusnya mampu pula bersepakat tentang satu sistem hukum yang berlaku bagi seluruh rakyat dan warga negara tanpa kecuali. Bahkan ilmu hukum nasional dikembangkan berdasarkan wawasan nusantara, wawasan yang bertolak dari arti "bangsa" atau "nation" Indonesia yang modern".

\footnotetext{
${ }^{4}$ Mochtar Kusumaatmadja, Hukum, Masyarakat, dan Pembinaan Hukum Nasional, Suatu Uraian tentang Landaan Pikiran, Pola dan Mekanisme Pembaruan Hukum di Indonesia, Binacipta, Bandung, 1976, dan dalam "Fungsi dan Perkembangan Hukum Dalam Pembangunan Nasional, Binacipta, Bandung, 1976. Lihat pula dalam CFG Sunaryati Hartono, Peranan Kesadaran Hukum Masyarakat dalam
} 


\section{Infografi 1. Perbedaan Unifikasi dengan Kodifikasi Hukum}

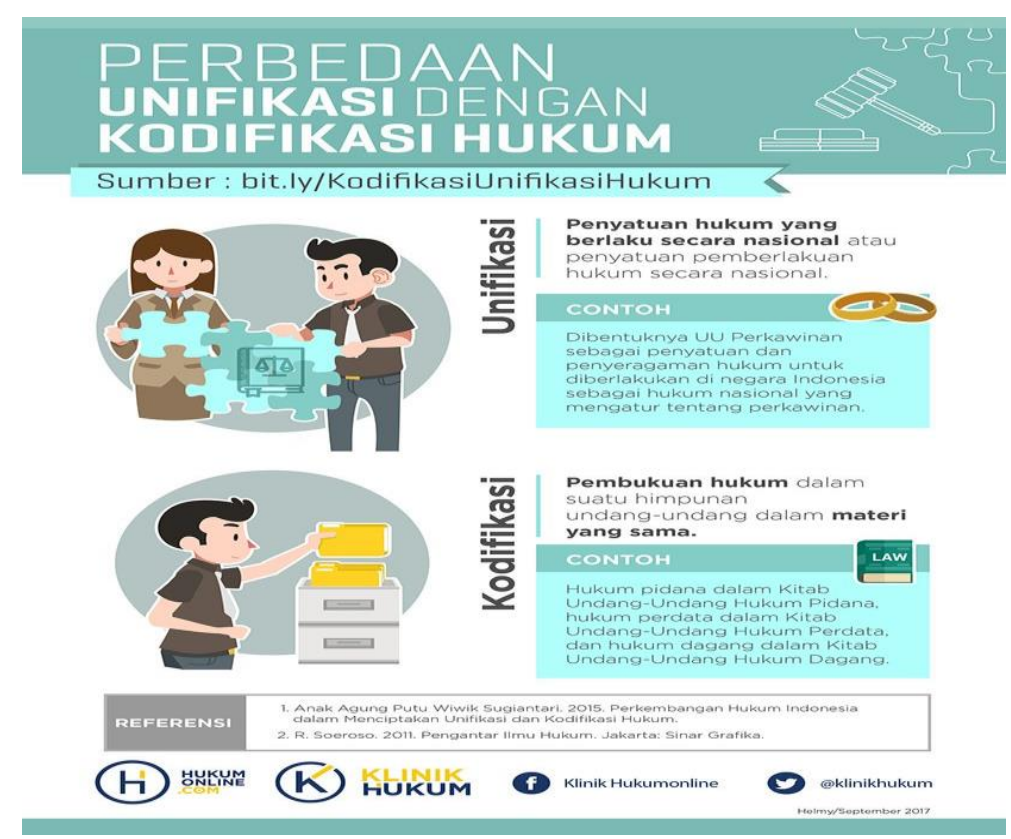

Sebagai negara bekas jajahan, usaha pemerintah Indonesia melakukan unifikasi dan pembaruan hukum nasional adalah termasuk pula upaya untuk mengani semua perundang-undangan warisan jaman pemerintahan Hindia Belanda dengan perundangundangan produk nasional. Pembaruan hukum nasional dilakukan dengan titik tolak bahwa produk perundang-undangan yang berlaku di wilayah NKRI harus berangkat dari dan mencerminkan nilai-nilai masyarakat Indonesia sendiri. Pembaruan hukum nasional juga dilakukan dalam rangka mnghadapi tantangan kecenderungan globalisasi ekonomi dan penerimaan sistem ekonomi pasar dunia yang semakin menguat.

Dalam konteks pembaruan hukum nasional, upaya mengganti hukum kolonial dengan hukum nasional terjalin erat dengan upaya national building, modernisasi, dan pembangunan bangsa. Ketetapan MPR No. X/ MPR/ 1998, menegaskan kembali bahwa tujuan penyelenggaraan negara adalah melaksanakan pembangunan secara terencana dan berkenaan dengan reformasi, pembangunan hukum mencanangkan pembentukan satu sistem hukum nasional melalui program legislasi nasional secara terpadu. Program inilah yang kemudian dicanagkan kembali di dalam UU No. 25 tahun 2000 tentang Program Pembangunan Nasional Tahun 2000-2004. Dengan demikian upaya pembaruan hukum dan pembangunan hukum nasional menempatkan hukum tertulis 
sebagai andalan utama, baik sebagai sarana kontrol untuk mewujudkan ketertiban dan keamanan, maupun sebagai sarana pembaruan masyarakat (social enginering) ${ }^{5}$.

Dalam konteks pembaruan hukum melalui hukum buatan negara (law state) dan sejalan dengan organisasi ketatanegaraan yang mengerucut, dikembangkan dan diberlakukan hirarkhi peraturan perundang-undangan yang menempatkan Pancasila sebagai sumber dari segala sumber hukum. Tata urutan perundang-undangan ini menempatkan Pancasila dan Undang-Undang Dasar 1945 sebagai alat ukur untuk menguji keselarasan peraturan perundang-undangan dari strata bawah dengan yang ada di atasnya. Dengan perkataan lain, di dalam wilayah Indonesia harus berlaku satu tata hukum nasional yang mengacu kepada satu tata nilai bernegara.

Keberlakuan prinsip dan hirarki tata urutan perundang-undangan dan penciptaan suatu tata hukum yang logis tersebut, Mahkamah Konstitusi diberi kewenangan untuk menguji materi perundang-undangan sebagai interpretasi dan pelaksanaan konstitusi. Mahkamah Agung mempunyai hak uji terhadap peraturan perundang-undangan di bawah undang-undang, sedangkan Menteri Dalam Negeri berwenang membatalkan peraturan daerah yang menyimpang dari batasan yang ditetapkan oleh Undang-Undang Otonomi Daerah. Dalam prakteknya, yang menjadi persoalan adalah kenyataan masih adanya pruralisme hukum di Indonesia. Kenyataan akan masih adanya produk hukum warisan Hindia Belanda yang belum diganti dengan hukum nasional, keragaman hukum adat maupun hukum Islam berhadapan dengan politik hukum unifikasi dan modernisasi. Berkaitan dengan hal ini, maka kebijakan pembangunan hukum nasional diarahkan untuk mengupayakan pengantian hukum warisan kolonial, pengkooptasian hukum adat (yang kebanyakan tidak tertulis) yang sangat beragam ${ }^{6}$, dan hukum Islam ke dalam dan menjadi bagian dari hukum positif negara ${ }^{7}$.

\footnotetext{
${ }^{5}$ Tristam P. Moeliono, Kebijakan Unifikasi Hukum dan Pruralisme Hukum, Paper untuk Semiloka bertema " Perkembangan Konsep dan Konteks Negara Hukum di Indonesia" yang diselenggarakan atas kerjasam PSHK, HuMa, dan Fakultas Hukum Universitas Parahiyangan, Bandung, 24 September 2004. Dapat dibaca pula dalam Jurnal Hukum "Jentera" Edisi 3 Tahun II, November 2004, hlm. 23

${ }^{6}$ Sebagai salah satu contoh adalah UU No. 5 Tahun 1960 tentang Pokok- Pokok Agraria yang mengangkat konsep hak ulayat menjadi suatu asas hukum pertanahan nasional dan sekaligus menghapuskan hak masyarakat adat atas tanah tempat tinggal mereka dimana mereka hidup dan bertempat tinggal.

${ }^{7}$ Jimly Assiddiqie, Hukum Islam dan Reformasi Hukum Nasional, Makalah dalam Seminar Penelitian Hukum tentang Eksistensi Hukum Islam dalam Reformasi Sistem Hukum Nasional, diselenggarakan oleh BPHN, Departemen Kehakiman dan HAM RI, Jakarta, 27 September 2006
} 
Dalam perjalanan waktu, perubahan politik, dan pemerintahan, tujuan pembetukan negara modern dan negara kesatuan dengan meniscayakan pembentukan satu sistem hukum modern di Indonesia yang multi kultural adalah suatu tantangan bagi semua pihak yang berkepentingan. Pada satu sisi negara berusaha untuk membetuk satu unifikasi hukum, namun pada sisi lain terdapat kenyataan produk-produk hukum (seperti misalnya hUU No. 5 Tahun 1960 tentang Pokok-pokok Agraria dan UU No. 1 Tahun 1974 tentang Perkawinan) yang membuka peluang bagi keberlakua hukum adat dan hukum agama/ kepercayaan. Dalam negara Indonesia modern, masyarakat adat dan hukum adat yang berbeda dengan hukum negara merupakan kenyataan empirik. Pengakuan atau penafian eksistensi masyarakat adat oleh aparat negara (dalam bentuk hukum apapun juga) hanya bersifat deklaratif, tidak konstitutif. Reaksi masyarakat adat dan komunitas lokal yang terpinggirkan mencuat seturut melemahnya hegemoni pemerintah pusat pada pasca krisis ekonomi dan bergulirnya reformasi.

Pengakuan dan penghormatan atas eksistensi masyarakat adat seperti dalam Pasal 18 B ayat (2) UUD 1945 Amandemen ke 5 yang menyatakan bahwa "negara mengakui dan menghormati kesatuan-kesatuan masyarakat hukum adat beserta hak-hak tradisonalnya", dan pernyataan bahwa "sepanjang masih hidup dan sesuai dengan perkembangan masyarakat dan prinsip Negara Kesatuan Republik Indonesia, yang diatur dalam undang-undang", pada dasarnya adalah merupakan suatu harapan bahwa masyarakat adat suatu saat kelak, berkat pendidikan modern atau penetrasi dari budaya luar, akan berkembang menjadi masyarakat modern yang menguasai tanah berdasarkan hak individu dan bukan hak komunal. Bagaimanapun juga negara wajib menghormati dan memberi pengakuan akan eksistensi sistem hukum adat di samping dan sederajat dengan hukum negara.

\section{Dinamika Pelaksanaan Otonomi Daerah}

Reformasi hubungan pemerintah pusat dan pemerintah daerah telah dimulai dengan diberlakukannya UU No. 22 Tahun 1999 jo UU No. 22 Tahun 2004 tentang Pemerintah Daerah dan UU No. 25 Tahun 1999 tentang Perimbangan Keuangan Antara Pemerintah Pusat dan Pemerintah Daerah. Perkembangan pelaksanaan otonomi daerah sejak digulirkannya Undang-Undang No. 22 Tahun 1999 tentang Pemerintahan Daerah yang terakhir diubah dengan Undang-Undang Republik Indonesia Nomor 9 Tahun 2015 tentang Perubahan Kedua Atas Undang-Undang Nomor 23 Tahun 2014 tentang Pemerintahan Daerah, menunjukkan dinamika yang beragam. Berbagai pengaruh dari 
pelaksanaan otonomi di tingkat pemerinta daerah dan implikasinya berkembang seiring dengan kesiapan pemerintah daerah dalam mengimplementasikan kewenangan dan tanggung jawab yang dilimpahkan oleh undang-undang.

Salah satu dasar pemikiran dipilihnya otonomi daerah sebagai asas penyelenggaraan pemerintahan daerah adalah pengaturan dan penyelenggaraan urusan pemeritahan dapat dilaksanakan secara efisien dan efektif. Dengan otonomi daerah, pemerintah daerah diberi keleluasaan dan kemandirian untuk mengatur berdasarkan kewenangan atributif dan diskresi yang dimilikinya. Berdasarkan kewenangan pemerintah daerah yang demikian ini permasalahan yang kemudian muncul adalah pada satu sisi pemerintah daerah terlalu responsif sehingga muncul produk-produk peraturan daerah yang melampauai kewenangan yang dimilikinya, namun pada sisi lain terdapat daerah yang bersifat pasif, yang masih menunggu dorongan dan inisiatif dukungan dari pemerintah pusat ${ }^{8}$.

Berbagai permasalahan muncul berkaitan dengan pelaksanaan otonomi dan desentralisasi kewenangan daerah. Implementasi kedua undang-undang tersebut membawa implikasi yang luas terhadap manajemen otonomi daerah dari berbagai aspek seperti : kelembagaan, peraturan daerah, sumber daya manusia, dan keuangan. Keberhasilan desentralisasi dan otonomi daerah juga tidak terlepas dari kemampuan manajemen otonomi daerah dalam menyelenggarakan pemerintahan daerah ${ }^{9}$. Dengan menengok kembali kebelakang sebagai bentuk instrospeksi dalam praktek penyelenggaraan pemerintahan daerah, belum satu tahun pelaksanaan Undang-undang No. 22 Tahun 1999 tentang Pemerintahan Daerah dan Undang-undang No. 25 Tahun 1999 tentang Perimbangan Keuangan Antara Pemerintah Pusat dan pemerintah daerah, telah banyak menimbulkan perdebatan dan kritikan.

Berbagai permasalahan muncul berkaitan dengan pelaksanaan otonomi daerah. Implementasi otonomi daerah beberapa diantaranya memunculkan berbagai intepretasi yang bersifat kedaerahan. Kasus-kasus pengambilalihan kewenangan pemungutan jasa dan pengelolaan sarana umum maupun pembagian hasil atas sumber penerimaan atau

\footnotetext{
${ }^{8}$ I Gde Pantja Astawa, Dinamika Otonomi Dalam Kerangka Negara Hukum, Pasca Berlakunya UU No. 22 Tahun 1999 tentang pemerintahan Daerah, Paper untuk Semiloka bertema “ Perkembangan Konsep dan Konteks Negara Hukum di Indonesia" yang diselenggarakan atas kerjasam PSHK, HuMa, dan Fakultas Hukum Universitas Parahiyangan, Bandung, 24 September 2004. Dapat dibaca pula dalam Jurnal Hukum "Jentera” Edisi 3 Tahun II, November 2004, hlm. 41-42

${ }^{9}$ Bagir Manan, Hubungan Pusat dan Daerah Dalam Penyelenggaraan Otonomi Daerah, Seminar Otonomi Daerah dan Perimbangan Antara Pusat dan Daerah, Hatta Internastional Legal Concellours, Jakarta, Tgl. 20 Juni 1999, hlm. 8
} 
retribusi di daerah, merupakan salah satu konflik kewenangan yang muncul, baik antara Pemerintah Pusat dengan pemerintah daerah, pemerintah daerah dengan pemerintah daerah lainnya, antara instansi/ dinas dalam satu pemerintah daerah dengan dinas/ instansi lainnya berkaitan dengan pelaksanaan otonomi daerah ${ }^{10}$.

Pada sisi lain, penyelenggaraan otonomi di daerah dengan titik berat otonomi pada daerah kabupaten, menuntut adanya kesiapan sumber daya, sumber dana, responsibilitas, akuntabilitas, serta pranata sosial dari setiap pemerintah kabupaten, sehingga mampu untuk menerima hak, wewenang, dan tanggung jawab yang lebih besar dari pemerintah pusat dan atau pemerintah propinsi. Pemahaman akan tuntutan atas hak dalam mengelola rumah tangganya sendiri sangat wajar, sebab sistem pemerintahan sentralistik yang selama ini terjadi, telah menguras kekayaan dan sumber alam yang dimiliki daerah. Pemerintah pusat pada masa Orde Baru sering bertindak kurang adil dalam pembagian pendapatan dan kekayaan yang ada di daerah-daerah. Hubungan keuangan pusat dan daerah dimanapun dipandang sangat menentukan dalam kemandirian otonomi daerah.

Infografik 2. Desentralisasi dan Transformasi Politik Anggaran Pemerintah Daerah

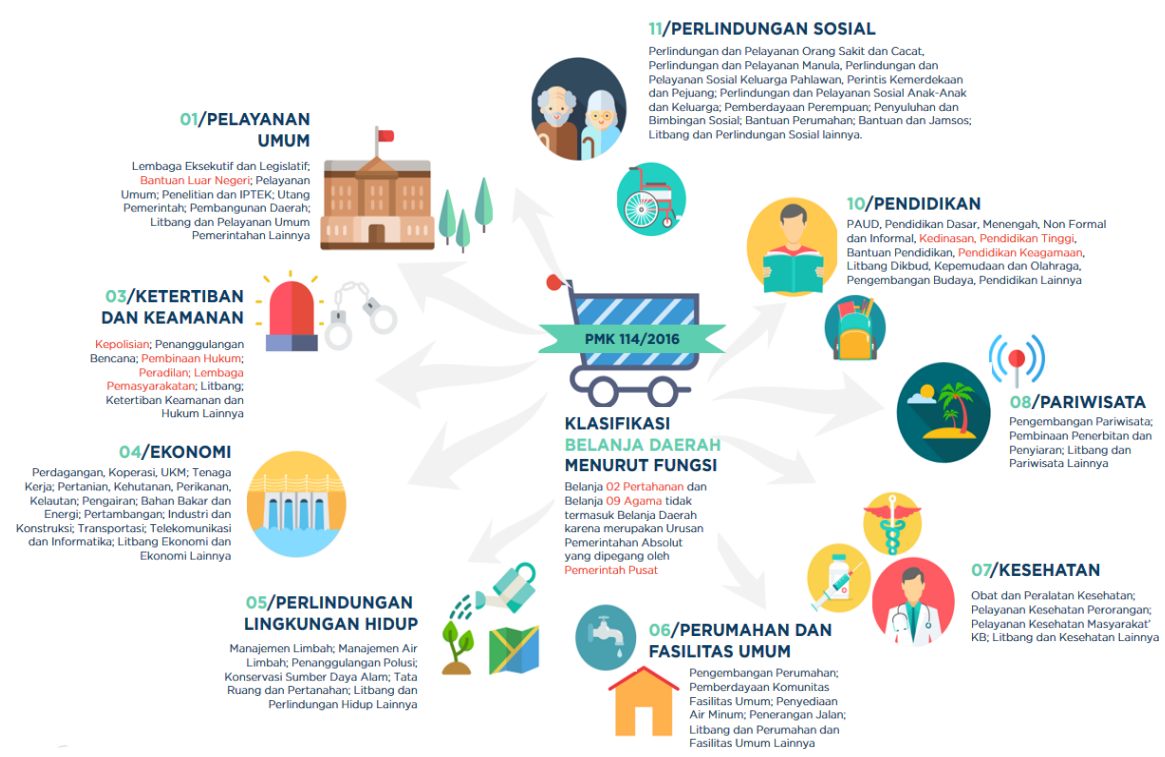

Sumber:https://medium.com/@luthfimuhamadiqbal/desentralisasi-dan-transformasipolitik-anggaran-pemerintah-daerah-57f12afd4eb1; laman diunduh pada tangal 26 Mei 2019

\footnotetext{
${ }^{10}$ Otonomi Daerah untuk Kesejahteraan Publik : antara Harapan dan Kenyataan, Harian Kompas Tanggal 25 September 2006
} 
Tujuan otonomi daerah dan desentralisasi kewenangan diantaranya adalah memperpendek birokrasi dan mengoptimalkan pelayanan publik. Dengan otonomi daerah, kepala daerah mempunyai tugas untuk menyelenggarakan pelayanan dan mewujudkan kesejahteraan publik. Pada kenyataannya yang terjadi adalah justru semakin memperpanjang proses birokrasi dan pelayanan publik. Berbagai distorsi dan anomali penggunaan kewenangan justru semakin meluas setelah dilaksanakannya otonomi dan desentralisasi kewenangan daerah. Potensi penyalahgunaan wewenang oleh penguasa daerah semakin marak, termasuk praktek-praktek koruptif yang semula sebagian besar hanya terkonsentrasi di pemerintahan pusat dilakukan pula di tingkat daerah. Demikian pula dengan sistem pemilihan kepala daerah yang dilakukan secara langsung, merupakan faktor yang semakin mendorong adanya konflik horozontal yang mengancam stabilitas dan disintegrasi bangsa ${ }^{11}$.

Persoalan yang juga muncul kemudian adalah minimnya sumber keuangan yang dimiliki daerah dibandingkan dengan yang dimiliki oleh pemerintah pusat. Berdasarkan hal itu, maka inti hubungan keuangan pusat dan daerah adalah berkaitan dengan perimbangan keuangan, sedangkan yang dimaksud dengan perimbangan tidak lain adalah memperbesar sumber pendapata asli daerah sehingga lumbung keuangan daerah dapat berisi lebih banyak. ${ }^{12}$ Kemampuan keuangan yang dimiliki daerah tersebut diharapkan akan mampu melaksanakan pembangunan dan meningkatkan kesejahteraan masyarakat di daerah.

Beberapa kasus sengketa kewenangan muncul antara daerah yang satu dengan lainnya, demikian pula konflik kewenangan antara pemerintah daerah dengan dinasdinas pemerintah pusat yang ada di daerah tak dapat dihindari sebagai akibat kurangnya pemahaman dan berbagai interpretasi kewenangan yang lebih mendahulukan kepentingan masing-masing daerah dan instansi yang terkait. Pengambilalihan kewenangan pemungutan jasa dan pengelolaan sarana umum maupun pembagian hasil atas sumber penerimaan atau retribusi di daerah, merupakan salah satu konflik kewenangan yang muncul, baik antara pemerintah pusat dengan pemerintah daerah, pemerintah daerah dengan pemerintah daerah lainnya, antara instansi/ dinas dalam satu

\footnotetext{
${ }^{11}$ I Gde Pantja Astawa, op.cit., hlm. 45

12 Bagir Manan, op.cit.., hlm. 9
} 
pemerintah daerah dengan dinas/ instansi lainnya berkaitan dengan pelaksanaan otonomi daerah $^{13}$.

Benang merah dari kusutnya pelaksanaan otonomi daerah sebagaimana terungkap dalam permasalahan dia atas pada dasarnya adalah berkaitan dengan klaim atas kewengan daerah dalam memperoleh, memanfaatkan, dan mengelola sumbersumber penerimaan daerah. Kemampuan daerah dalam menggali sumber-sumber keuangan dan penerimaan untuk menambah pundi-pundi anggaran pendapatan dan belanja daerah inilah yang merupakan konsekuensi otonomi daerah. Dengan demikian pemerintah daerah harus mampu mengoptimalkan potensi daerahnya masing-masing untuk mewujudkan pembangunan dan pelayanan publik yang menjadi tanggung jawabnya Suatu hal yang kemudian tidak boleh diabaikan untuk terlaksananya otonomi daerah adalah kemampuan keuangan daerah ${ }^{14}$.

\section{Simpulan}

Dari uraian dan penjelasan dalam bagian pendahuluan dan pembahasan tentang permasalahan di atas, maka dapat dirumuskan kesimpulan sebagai berikut : Pembaruan hukum nasional pada hakekatnya adalah proses politik yang keberhasilannya tergantung pada perimbangan kekuatan antar aktor yang terlibat di dalamnya serta mementum yang tersedia dan yang mampu dibangun oleh para aktornya. Pembaruan Hukum memerlukan ruang dan tempat bagi proses dialektik dan harus berangkat dari problem-problem nyata yang dihadapi masyarakat dan tanpa harus meninggalkan semua aspirasi dari seluruh golongan masyaakat. Tujuan pembetukan negara modern dan negara kesatuan dengan meniscayakan pembentukan satu sistem hukum modern di Indonesia yang multi kultural adalah suatu tantangan bagi unifikasi dan pembaruan hukum nacional. Penyelenggaraan otonomi daerah dimaksudkan untuk dapat mewujudkan pelayanan publik dan kesejahtraan masyarakat, pada satu sisi pemerintah daerah terlalu responsif dengan akibat memunculkan produk-produk peraturan daerah yang melampauai kewenangan yang dimilikinya. Pada sisi, lain terdapat daerah yang bersifat pasif, menunggu dorongan dan inisiatif dukungan dari pemerintah pusat.

Beberapa saran yang menjadi masukan atas pembahasan kajian pada artikel ini diantaranya adalah sebagai berikut: Pertama, Keberagaman sosial, budaya, adat-istiadat,

\footnotetext{
${ }^{13}$ Harian Kompas, op.cit. hlm 38

${ }^{14}$ Josef Riwu Kaho, Kapita Selekta Masalah-masalah Penyelenggaraan Pemerintahan Daerah di Bawah UU No. 5 Tahun 1974, Makalah Dipresentasikan Dalam Pembekalan Anggota DPRD I dan II seIndonesia, Jakarta, Oktober 1997 s/d Mei 1998
} 
tradisi masyarakat Indonesia adalah kekayaan yang menjadi modal bagi bangsa Indonesia untuk membangun karakter dan jati diri bangsa, sehingga merupakan modal sosial dan modal kapital utama bagi bangsa untuk reformasi hukum nasional yang mengadopsi nilai-nilai yang menjadi pandangan hidup dan jiwa bangsa; dan Kedua, Pembentukan hukum nasional harus dilandasi nilai-nilai yang memiliki jiwa keberagaman dan bukan merupakan bentuk penyeragaman berdasarkan proses politik yang lebih menekankan faktor-faktor mayoritas-minoritas, tetapi tetap mempertimbangkan berbagai aspek musyawarah da mufakat untuk persatuan dan kesatuan bangsa Indonesia.

\section{Daftar Pustaka}

Bagir Manan, Hubungan Pusat Daerah Dalam Penyelenggaraan Otonomi Daerah, Seminar "Otonomi Daerah dan Perimbangan Antara Pusat dan Daerah", Hata International Legal ConceLours, Jakarta, Tanggal 20 Juli 1999

CFG Sunaryati Hartono, Peranan Kesadaran Hukum Masyarakat dalam Pembaruan Hukum, Binacipta, Bandung, 1988

CFG Sunaryati Hartono, Politik Hukum Menuju Satu Kesatuan Sistem Hukum Nasional, Alumni, Bandung, 1991

Djaka Suhenedra, Realitas Kemajemukan Hukum Dalam Masyarakat, Paper untuk Semiloka bertema "Perkembangan Konsep dan Konteks Negara Hukum di Indonesia" yang diselenggarakan atas kerjasam PSHK, HuMa, dan Fakultas Hukum Universitas Parahiyangan, Bandung, 24 September 2004

Harian Kompas Tanggal 25 September 20016

Harian Kompas Tanggal 26 Juli, 21 Agustus. dan 2 September 20017

I Gde Pantja Astawa, Dinamika Otonomi Dalam Kerangka Negara Hukum, Pasca Berlakunya UU No. 22 Tahun 1999 tentang pemerintahan Daerah, Jurnal Hukum Jentera, Edisi Tahun II, Jakarta, Nopember 2004

Jimly Assiddiqie, Hukum Islam dan Reformasi Hukum Nasional, Makalah dalam Seminar Penelitian Hukum tentang Eksistensi Hukum Islam dalam Reformasi Sistem Hukum Nasional, diselenggarakan oleh BPHN, Departemen Kehakiman dan HAM RI, Jakarta, 27 September 2006

Josef Riwu Kaho, Kapita Selekta Masalah-masalah Penyelenggaraan Pemerintahan Daerah di Bawah UU No. 5 Tahun 1974, Makalah Dipresentasikan Dalam Pembekalan Anggota DPRD I dan II se- Indonesia, Jakarta, Oktober 1997 s/d Mei 1998

Jurnal Hukum "Jentera" Edisi 3 Tahun II, November 20014

Mochtar Kusumaatmadja, Fungsi dan Perkembangan Hukum Dalam Pembangunan Nasional, Binacipta, Bandung, 1976

Mochtar Kusumaatmadja, Hukum, Masyarakat, dan Pembinaan Hukum Nasional, Suatu Uraian tentang Landasan Pikiran, Pola dan Mekanisme Pembaruan Hukum di Indonesia, Binacipta, Bandung, 1976,

Tristam P. Moeliono, Kebijakan Unifikasi Hukum dan Pruralisme Hukum, Jurnal Hukum "Jentera", Edisi 3 Tahun II, November 2004 